\title{
Obligation to Exchange Views under Article 283 of the United Nations Convention on the Law of the Sea: An Empirical Approach for Improvement
}

\author{
Deyi $\mathrm{Ma}^{*}$
}

The obligation to exchange views within the UNCLOS did not play its systematic role. The disputing parties are uncertain about the scope, mode, and standard of the obligation to exchange views, with adjudicators demonstrating their subjective tendencies. The low threshold of the provisional jurisdiction of maritime disputes, the emergence of jurisdiction over hybrid disputes, and the congenital deficiency of the dispute settlement mechanism of the UNCLOS address the obligation to exchange views which has not fully reflected the initial legislative intention and aim of the UNCLOS. The South China Sea Arbitration initiated by the Philippines demonstrates that the obligation to exchange views may be perfected and improved, to some extent, by enhancing the parties' obligation of disclosure and the tribunal's obligation of review. Where relevant unilateral or bilateral agreements exist regulating such type of disputes before the disputing parties initiate the compulsory arbitration procedure of the UNCLOS, the obligation to exchange views should be conducted with sufficient regard for the existence of such agreement.

\section{Keywords}

Treaty Interpretation, Obligation to Exchange Views, Obligation to Disclosure, Mixed Disputes

* Professor of Law at East China University of Political Science and Law (ECUPL), China. LL.M./Ph.D. (Dalian Maritime Univ.). ORCID: http://orcid.org/0000-0001-5093-8177. The author would like to thank Dr. Chenling for her insightful advice. All errors and omissions remain his own. This research is supported by the National Office for Philosophy and Social Sciences (18ZDA155). The author may be contacted at: madeyi9@aliyun.com/Address: International Law School, East China University of Political Science and Law, No. 1575 Wanghangdu Road, Shanghai, P.R. China 200042. 


\section{Introduction}

As a critical legal achievement of the global governance over the sea, the United Nations on the Law of the Sea of 1982 ("UNCLOS") creates a system by using "a package deal" as "a constitution for the oceans." One highlight of the UNCLOS is the dispute settlement mechanism as a systematic set, which is laid down in Part XV of as well as in several Annexes to the UNCLOS. Its innovation lies in both designing a binding dispute settlement mechanism by peaceful means, and establishing alternative dispute resolutions. The UNCLOS is not an isolated system. It enhances the importance of dispute settlement through peaceful means, by paying sufficient regard to the spirit and demands of international law, such as the provisions of the Charter of the United Nations. ${ }^{1}$ To realize the legislative aim of Part XV, the UNCLOS sets forth preconditions for "Compulsory Procedures Entailing Binding Decisions," such as obligations under general, regional, or bilateral agreements, and obligations to exchange views and conciliation. ${ }^{2}$ Among these, the "obligation to exchange views" set forth in Article 283 of the UNCLOS is one of the issues worthy of attention.

Different opinions exist regarding how to determine the standard for both disputing parties' sufficient performance of the obligation to exchange views and how to exchange views as the compulsory measures entailing binding decisions. Relevant cases indicate that the requirement of Article 283 has been satisfied even though no real exchange of views occurs if one party to a dispute has made efforts to exchange views, but both parties fail to exchange views because of the other party. ${ }^{3}$ In a word, the obligation to exchange views in Article 28 of the UNCLOS seems extremely uncertain. In this paper, the author will take relevant cases including the South China Sea Arbitration to empirically explore practices related to the obligation to exchange views. In addition, the author will tackle the principal issues concerning the obligation to exchange views under the UNCLOS from a viewpoint of treaty interpretation and strive to review them and offer reflections. Finally, the author will seek a possible approach of improving the obligation to exchange views.

1 R. Churchill \& A. Lowe, The Law of the Sea190 (1999).

2 United Nations Convention on the Law of the Sea (adopted 10 December 1982, entered into force 16 November 1994), 1833 U.N.T.S. 396, arts. 282, 283 \&284.

3 Jianjun Gao, Dispute Settlement System Under the U N Convention on the Law of the Sea [联合国海洋法公约争端 解决机制研究] $176 \& 187$ (2014).

4 This paper deals with the following cases: the South Bluefin Tuna Case, the MOX Plant Case (Ire. v. U.K.); the Straits of Johor Land Reclamation Case (Malay. v. Sing.); the Bay of Bengal Delimitation Case (Bangladesh v. Myanmar); the Arctic Sunrise Case (Neth. v. Russ.), Provisional Measures of South China Sea Arbitration Case, etc. 


\section{Why does the UNCLOS Enhance the Obligation to Exchange Views?}

The General Provisions of Part XV of the UNCLOS are set forth separately in "Obligation to Exchange Views" and 'Conciliation' as the antecedent text of compulsory procedures entailing binding decisions initiated because of any dispute concerning the interpretation or application of this Convention. Therefore, the obligation to exchange views becomes one of the preconditions for initiating compulsory procedures entailing biding decisions with the legislative aim and intention of preventing any dispute from easily entering into compulsory procedures. It plays a "safety valve" role in dispute settlement through due process.

In addition, legislatively speaking, the 'status' of obligation to exchange views should be higher than Section 2 of "Compulsory Procedures Entailing Binding Decisions" and Section 3 of "Limitations and Exceptions to Applicability of Section 2." From the perspective of the text structure and the aim of Part XV of the UNCLOS, the performance of the obligation to exchange views is the prelude to introduce Section 2 of Part XV of the UNCLOS, for example, "Compulsory Procedures Entailing Binding Decisions." The obligation to exchange views plays a critical role in bridging the peaceful settlement of a dispute; it not only guarantees a mechanism of consultation and other peaceful means of dispute settlement, but also valves initiating compulsory procedures. ${ }^{5}$ A theoretical explanation is the following: the aim of Paragraph 1 of Article 283 of the UNCLOS is for the parties to the dispute to exchange views expeditiously after the dispute arises. In addition, the aim of Paragraph 2 is to clarify that, even in the circumstance where the parties cannot settle the dispute by using peaceful means they have chosen, the parties shall not immediately resort to compulsory procedures, but exchange views. ${ }^{6}$

A deep understanding of the systematic value of the obligation to exchange views cannot be limited to the UNCLOS itself. The settlement of maritime disputes

5 From the perspective of the sequence of articles in Section 1 of Part XV of the UNCLOS and the background of negotiating the aforesaid articles, Article 283 clarifies the means or procedures for peaceful settlement of a dispute. Therefore, the disputing parties are obliged to expeditiously exchange views after the dispute arises. The parties shall also proceed expeditiously to an exchange of views where a procedure for the settlement of such a dispute has been terminated without a settlement.

6 Ying chun Gong, The Applicability of Dispute Settlement Procedures under the Framework of United Nations Convention on the Law of the Sea: Premise, Condition, Limitation and Exception-Also Review on South China Sea ARBITRATION [《联合国海洋法公约》框架下争端解决程序的适用: 前提、条件、限制和例外-兼评菲律宾南海仲裁案], ๆ 9, available at https://www.chinalaw.org.cn/Column/Column_View.aspx?ColumnID=893\&InfoID=20072. 
not only depends on the dispute settlement mechanism within the framework of the UNCLOS, but also on principles and rules that general international law addresses. Paragraph 1 of Article 33 of the UN Charter confirms that negotiation is one of the peaceful means used for international dispute settlement. In addition, numerous instruments of international law have recognized negotiation as a means of dispute settlement. Article 283 of the UNCLOS closely coordinates with and corresponds to Article 281 of the UNCLOS. When parties cannot solve a maritime dispute through protracted consultation and negotiation, the hope of settling a dispute cannot be placed exclusively on the exchange of views. ${ }^{7}$ In understanding the obligation to exchange views, therefore, it is essential to realize the systematic nature of such an obligation in the maritime dispute settlement mechanism.

\section{The Application of the Exchange of Views and Its Defects}

\section{A. Means of Exchanging Views}

According to Paragraph 1 of Article 283 of the UNCLOS, the parties' means of exchanging views to a dispute include 'negotiation' or "other peaceful means." The text also indicates that parties shall exchange such views 'expeditiously.' Therefore, when a dispute arises on how to interpret and apply this Convention, the means that parties adopt in the dispute to exchange views is negotiation or other peaceful means. As regard procedure law, negotiation is a dispute settlement means that does not follow a strict procedure. Instead, the international law community regards it as an extremely general means of settling a dispute peacefully. "The negotiation process should first be exhausted." ${ }^{\prime 8}$ Academically, negotiation is a critical means of international dispute settlement among the instruments of international law. Because negotiation requires that both parties make necessary compromises and concessions, however, not all negotiations result in a solution binding upon both parties. ${ }^{9}$ The UNCLOS also emphasizes the pivotal role of negotiation in maritime dispute

7 H. Schiffmen, The Dispute Settlement Mechanism of the UNCLOS: A Potentially Important Framework for Marine Wildlife Management, 1 J. INT'L WILDLIFE L. \& PoL'y 293-306 (1998).

8 Case concerning Land Reclamation by Singapore In and Around the Straights of Johor (Malay. v. Sing.), Provisional Measures of Oct. 8, 2003) (separate opinion of Judge Ndiaye), ITLOS Rep. 48-50, available at https://www.itlos.org/ fileadmin/itlos/documents/cases/case_no_12/12_order_081003_sep_op_Ndiaye_en.pdf.

9 Yoshiro Matsui et al., International Law [國際法] 231 (2004). 
settlement mechanism. In terms of maritime disputes, even though they fall under the rubric of interpretation or application of the UNCLOS, views that parties exchange through 'negotiation,' "other peaceful means," and "the manner of implementing the settlement" do not seem to be possibly limited to the procedural level, but are approximately related to the substantive issues of the dispute. Moreover, a maritime dispute is extremely complicated; it is thus difficult to offer a clear distinction between procedural and substantive issues in a maritime dispute settlement mechanism.

\section{B. Standard for Full Performance of Obligation to Exchange Views and Its Defects}

In Arctic Sunrise (Netherlands v. Russia), Judge Anderson expressed the standard for assessing the 'sufficiency' that "when a dispute arises concerning the interpretation or application of the Convention, a State to the dispute is not taken completely by surprise by the institution of proceedings against it." ${ }^{10}$ The aim of Article 283 of the UNCLOS is to let each party know the other party's intention of filing a claim to the dispute settlement mechanism under the UNCLOS. In different maritime disputes, diverse standards for understanding 'deadlock' exist. In Straits of Johor Land Reclamation (Malaysia v. Singapore), the tribunal holds that the parties have engaged in long-standing, intense, and sincere consultation, thereby satisfying the condition set forth in Article 283 of the UNCLOS. ${ }^{11}$ However, this does not mean that parties to a dispute are required to consult and negotiate indefinitely. Generally, a failure to settle a dispute through consultation becomes a deadlock. However, M/ $V$ 'Louisa'(Saint Vincent and the Grenadines v. Spain) shows that the application of Article 283 of the UNCLOS is an empty formality. One judge expressed in his separate opinion that whether a sufficient exchange of views has taken place between the Parties depends on whether the applicant could prove that the exchange of views had totally failed and the dispute could not be settled by exchanging views. ${ }^{12}$ The 'deadlock' standard is not used solely for assessing the obligation to exchange views, and other standards that gradually developed in the practice of international law

10 Arctic Sunrise (Neth. v. Russ.), Provisional Measures (Declaration of Judge Anderson), Order of Nov. 22, 2013, ITLOS Rep., available at $\mathrm{https} / /$ www.itlos.org/fileadmin/itlos/documents/cases/case_no.22/published/C22_Anderson_221113. pdf.

11 Land Reclamation by Singapore In and Around the Straights of Johor (Malay. v. Sing.), Case No.12, Order of Oct. 8, 2003, ITLOS Rep. ๆ 48, available at https://www.itlos.org/fileadmin/itlos/documents/cases/case_no_12/12 order_081003_en.pdf.

12 The M/V "Louisa" Case (St. Vincent \& the Grenadines v. Spain), Case No.18, Provisional Measures (Dissenting Opinion of Judge Wolfrum), Order of Dec. 23, 2010, ITLOS Rep., available at https://www.itlos.org/fileadmin/itlos/ documents/cases/case_no_18_prov_meas/18_order_231210_dis_op_Wolfrum_en.pdf. 
usually describe the degree of obligation to exchange views from another perspective.

Comparing to the 'deadlock' standard, the 'exhaustion' standard has different definitions in different cases. Straits of Johor Land Reclamation provides a preliminary explanation of the 'exhaustion' standard by which a party is not obliged to continue with an exchange of views if such exchange "could not yield a positive result."13 So did Southern Bluefin Tuna, as well. ${ }^{14}$ Its award showed that the pivotal role of Article 286 of the UNCLOS had been enhanced; one must understand such article in the context satisfying overall conditions of Articles 279 and 280. As Rosenne stated, Articles 281 and 282 of the UNCLOS reflect similar procedures and subject to performance of the prior obligation to exhaust other peaceful means or negotiation, which is reflected in Article 283 of the UNCLOS. ${ }^{15}$ The awards of the Southern Bluefin Tuna and the MOX Plant Cases almost held with one accord that a disputant was not obliged to continue exchanging views if the arbitral tribunal concluded that the possibility for both parties to reach an agreement was exhausted. ${ }^{16}$ The 'exhaustion' standard is truly uncertain and unstable, so that its definite and clear connotation does not subsist.

Either the 'deadlock' standard or the 'exhaustion' standard has explicit defects. ${ }^{17}$ In practice, numerous arbitral tribunals for maritime disputes did not identify the 'exhaustion' of obligation to exchange views or set forth a stable standard for defining the 'deadlock.' For the arbitral tribunal seeking the "true intention" of disputants is critical and such "true intention" must be based on the disputants' consensus. The UN Charter and its relevant framework of international law would construct the framework of influential peaceful means of settling maritime disputes, including the settlement of international disputes according to the principle of consent on arbitration by the third party. ${ }^{18}$ However, the deficiencies of the UNCLOS in dispute settlement mechanisms would thus lead to defects in the obligation to exchange views under Article 283 thereof. The dispute settlement mechanism (including Annex VII) under the framework of the UNCLOS suffers from a systematic flaw. The

13 Supra note 11, 9 - 66-74.

14 Southern Bluefin Tuna Cases (N.Z. v. Japan; Austl. v. Japan), Case No. 3\&4, Provisional measures, Order of Aug. 27, 1999, ITLOS Rep. 25-28, available at https:/www.itlos.org/fileadmin/itlos/documents/cases/case_no_3_4/published/ C34-O-27_aug_99.pdf.

15 B. Kwiatkowska, The Southern Bluefin Tuna Arbitral Tribunal Did Get It Right: A Commentary and Reply to the Article by David A. Colson and Dr. Peggy Hoyle, 34 Ocean Dev. \& Int'L L. 369-95 (2003).

16 Response and Counter-Request for Provisional Measures Submitted by Japan, $9 \uparrow$ 73-79, available at https://www.itlos. org/fileadmin/itlos/documents/cases/case_no_3_4/statement_response_japan_eng.pdf.

17 G. Giraudeau, A Slight Revenge and a Growing Hope for Mauritius and the Chagossians: The UNCLOS Arbitral Tribunal's Marine Protected Area (Mauritius v U.K.), 12:2 Revista Internacional De Andrología 704-26 (2015).

18 Kwiatkowska, supra note 15. 
international legal proceedings may be applied only upon the disputing states with the agreement which is made as either a general accord on specific types of issues or a special agreement regarding a particular case or request for application. ${ }^{19}$

\section{Why Cannot Disputants Fully Exchange Their Views?}

Recently, in numerous international contentious or arbitration cases, the disputants almost without exception, have been required to fulfill their obligation to exchange views. The disputants almost did not exchange their views fully or effectively when they had an obligation to exchange views according to the UNCLOS. This would easily introduce binding jurisdiction, thereby resulting in "losing control" of Article 283 of the UNCLOS in most situations and in this article's failure to preventing compulsory procedures being introduced. ${ }^{20}$ Since nearly half a century ago, the threshold of preliminary jurisdiction over a dispute regarding the interpretation or application of the UNCLOS has shown the tendency of decline. From the cases referred to in Table 1, it is deduced that the Arbitral Tribunal in the Delimitation Case (Barbados v. Trinidad \& Tobago) held that provisions on the obligation to reach a delimitation agreement in the aforesaid articles are overlapped to some extent. This shows that the threshold of preconditions for applying the compulsory arbitration proceedings set forth in Annex VII to the UNCLOS is increasingly becoming lower so that no substantial results is required for the exchange of views. ${ }^{21}$ In the Delimitation Case, the arbitral tribunal held that, to some extent, the obligation to reach an agreement on delimitation and the obligation in these articles overlap. ${ }^{22}$

This demonstrates that the threshold of preconditions for compulsory procedures set forth in Annex VII to the UNCLOS is being lowered and the exchange of views is not required to yield a positive result. In Arctic Sunrise, the court considered that the exchange of views existed in diplomatic notes and governmental documents relating to the dispute as of September 18, 2013. ${ }^{23}$ When it was impossible to reach an agreement through negotiation, the Netherlands was not obliged to continue exchanging views with Russia. ${ }^{24}$ All this demonstrated that greater attention is paid to disputants'

19 Xianhe Yi, On Involvement in the Arbitral Procedure under Annex VII to United Nations Convention on the Law of the Sea [介入联合国海洋法公约附件七下仲裁程序], 6 INT’L L. REV.] [国际法研究] 18 (2015).

20 T. Ndiaye \& R. Wolfrum, Law of the Sea, Environmental Law and Settlement of Disputes, Liber Amicorum, Serge Thomas A. Mensah 891 (2007).

21 Delimitation Case (Barbados v. Trin. \& Tobago), 27 R.I.A.A. 147, 1213 (Perm. Ct. Arb., 2006).

22 Id. at 61-4, ๆๆ 199-207, available at $\mathrm{https}: / /$ pcacases.com/web/sendAttach/1116.

23 ITLOS, Latest News, available athttp://www.itlos.org/index.php? Id=264\&L=0 and 7\%3D2.

24 Shicun Wu, Selected Latest CASes of International Law of the Sea [国际海洋法最新案例精选] 122 (2016). 
intention to exchange views in terms of performing the obligation to exchange views than to the success in reaching an agreement. Thus, the author may suppose that the threshold of obtaining the jurisdiction is extremely low, which is an essential reason for preventing the successful fulfillment of the obligation to exchange views.

Table 1: Application of the Obligation to Exchange Views ${ }^{25}$

\begin{tabular}{|c|c|c|c|}
\hline Cases & Disputes & $\begin{array}{l}\text { The Obligation to } \\
\text { Exchange Views }\end{array}$ & $\begin{array}{l}\text { The Arbitral Tribunal's } \\
\text { Opinion on the Exchange } \\
\text { of Views }\end{array}$ \\
\hline $\begin{array}{l}\text { Arbitration between } \\
\text { Mauritius and the } \\
\text { United Kingdom }\end{array}$ & $\begin{array}{l}\text { Establishment } \\
\text { of a Marine } \\
\text { Protected Area }\end{array}$ & $\begin{array}{l}\text { The exchange of views } \\
\text { on the legality and } \\
\text { boundary of Marine } \\
\text { Protected Area }\end{array}$ & $\begin{array}{l}\text { The exchange of views is } \\
\text { not an empty formality. }\end{array}$ \\
\hline $\begin{array}{l}\text { Delimitation of the } \\
\text { Maritime Boundary } \\
\text { Between Bangladesh } \\
\text { and Myanmar } \\
\text { in the Bay of Bengal }\end{array}$ & $\begin{array}{l}\text { Dispute } \\
\text { concerning the } \\
\text { Delimitation } \\
\text { of the Maritime } \\
\text { Boundary }\end{array}$ & $\begin{array}{l}\text { Eleven rounds of } \\
\text { negotiation have } \\
\text { been regarded as } \\
\text { fulfillment of } \\
\text { exchange of views. }\end{array}$ & $\begin{array}{l}\text { Both parties did not } \\
\text { announce a declaration to } \\
\text { exclude the application of } \\
\text { procedures set forth in Part } \\
\text { XV of the UNCLOS. }\end{array}$ \\
\hline $\begin{array}{l}\text { Delimitation Case } \\
\text { (Barbados v. } \\
\text { Trinidad and } \\
\text { Tobago) }\end{array}$ & $\begin{array}{l}\text { Delimitation } \\
\text { of a Maritime } \\
\text { Boundary } \\
\text { between the } \\
\text { Exclusive } \\
\text { Economic } \\
\text { Zones and the } \\
\text { Continental } \\
\text { Shelves }\end{array}$ & $\begin{array}{l}\text { Trinidad required } \\
\text { Barbados to perform } \\
\text { its obligation to } \\
\text { exchange views, } \\
\text { but Barbados } \\
\text { believed that if } \\
\text { a state expressed } \\
\text { the intention of } \\
\text { "Let us talk", } \\
\text { the arbitration } \\
\text { would be terminated. }\end{array}$ & $\begin{array}{l}\text { The obligation to reach an } \\
\text { agreement on delimitation } \\
\text { and the obligation to } \\
\text { exchange views overlap. } \\
\text { If the disputants cannot } \\
\text { settle the dispute through } \\
\text { negotiation within a } \\
\text { reasonable period, then no } \\
\text { deed exists for any party } \\
\text { to additionally exchange } \\
\text { views on dispute settlement } \\
\text { through negotiation. }\end{array}$ \\
\hline $\begin{array}{l}\text { Delimitation of } \\
\text { Maritime Boundary } \\
\text { Between Guyana } \\
\text { and Suriname }\end{array}$ & $\begin{array}{l}\text { Delimitation } \\
\text { of a Maritime } \\
\text { Boundary }\end{array}$ & $\begin{array}{l}\text { Suriname considered } \\
\text { that the provision } \\
\text { in Article } 283 \text { of the } \\
\text { UNCLOS constituted } \\
\text { an exclusion of the } \\
\text { jurisdiction of an } \\
\text { arbitral tribunal. }\end{array}$ & $\begin{array}{l}\text { The incident that patrol } \\
\text { boats from the Surinamese } \\
\text { navy expelled CGX's vessels } \\
\text { was not isolated, but was } \\
\text { related to the whole dispute } \\
\text { concerning delimitation of } \\
\text { maritime boundary between } \\
\text { Guyana and Suriname; } \\
\text { therefore, Guyana was } \\
\text { not obliged to perform } \\
\text { separately its obligation } \\
\text { to exchange views. }\end{array}$ \\
\hline
\end{tabular}

25 Id. Compiled by the author based on the official websites of the International Court of Justice (ICJ), International Tribunal for the Law of the Sea (ITLOS) and the Permanent Court of Arbitration (PCA). 


\begin{tabular}{|l|l|l|l|}
\hline $\begin{array}{l}\text { The MOX Plant } \\
\text { Case Between } \\
\text { Ireland and United } \\
\text { Kingdom }\end{array}$ & $\begin{array}{l}\text { Marine } \\
\text { Environment }\end{array}$ & $\begin{array}{l}\text { Both parties had } \\
\text { exchanged views on } \\
\text { the jurisdiction } \\
\text { at the level of } \\
\text { international law }\end{array}$ & $\begin{array}{l}\text { A disputant has the right } \\
\text { to choose different judicial } \\
\text { organs, which shows the } \\
\text { respect of the parties' will. }\end{array}$ \\
\hline $\begin{array}{l}\text { The Arctic Sunrise } \\
\text { Case (Netherlands } \\
\text { v. Russia) }\end{array}$ & $\begin{array}{l}\text { Provisional } \\
\text { Measures }\end{array}$ & $\begin{array}{l}\text { The Netherlands } \\
\text { thought that it had } \\
\text { negotiated with } \\
\text { Russia on numerous } \\
\text { occasions. }\end{array}$ & $\begin{array}{l}\text { The diplomatic notes and } \\
\text { governmental documents } \\
\text { relating to the dispute are } \\
\text { typical exchanges of views. }\end{array}$ \\
\hline $\begin{array}{l}\text { The Straits of Johor } \\
\text { Land Reclamation } \\
\text { Case (Malaysia v. } \\
\text { Singapore) }\end{array}$ & $\begin{array}{l}\text { Marine } \\
\text { Environment }\end{array}$ & $\begin{array}{l}\text { Malaysia was not } \\
\text { obliged to continue } \\
\text { with the exchange of } \\
\text { views with Singapore. }\end{array}$ & $\begin{array}{l}\text { If a party to a dispute } \\
\text { believes that the dispute } \\
\text { cannot be settled through } \\
\text { the procedures set forth in } \\
\text { Section 1 of Part XV of the } \\
\text { UNCLOS, such party is } \\
\text { not obliged to apply such } \\
\text { procedures. }\end{array}$ \\
\hline
\end{tabular}

Hybrid disputes generally refer to disputes concurrently concerning the delimitation of maritime boundaries and territorial sovereignty. The terms of hybrid disputes originated from one of the informal proposals during the UNCLOS negotiations in $1979 .^{26}$ The existence of hybrid disputes is highly controversial in the practice of maritime dispute settlement. Some scholars would consider it necessary to include such type of disputes into the scope of the compulsory jurisdiction of the UNCLOS; ${ }^{27}$ otherwise, the UNCLOS's regulation of the marine order would be substantially limited. If the UNCLOS loses its compulsory jurisdiction over hybrid disputes, the provisions on its delimitation function of maritime boundaries would be worthless. Therefore, courts or arbitral tribunals have jurisdiction over territory-related issues. ${ }^{28}$ Conversely, others would believe that, if the scope of compulsory jurisdiction of the UNCLOS is so extensive even covering all maritime sovereignty issues, the UNCLOS itself is harmful to national sovereignty. ${ }^{29}$ Nothing in the UNCLOS text as such supports the ambitious interpretations concerning the expansion of its compulsory jurisdiction. ${ }^{30}$ Whatever the maritime dispute practices of recent years are, a theory

26 M. Nordquist et al. (eds.), United Nations Convention on the Law of the sea 1982: A Commentary, vol.5, ๆ 283(1) (1989).

27 S. Rosenne, The Law and Practice of the International Court (1920-2005) 1360 (2005).

28 NdiaYe \& Wolfrum, supra note 20.

29 T. Treves, What Have the United Nations Convention and the International Tribunal for the Law of the Sea to Offer as regards Maritime Delimitation Disputes?, in Maritime Delimitation 77 (R. Logoni \& D. Vignes eds., 2006).

30 B. Oxman, A Tribute to Louis Sohn: Is the Dispute Settlement System under the Law of the Sea Convention Working?, 39 Geo. Wash. L. Rev. 657 (2007). 
has gradually developed on the jurisdiction over hybrid dispute that stealthily increases the weakness of the obligation to exchange views.

The jurisdiction over hybrid disputes has become increasingly accepted and finally resulted in the expansion of the jurisdiction of the arbitral tribunal. ${ }^{31}$ In the course of hearing the case between Mauritius and the UK, the arbitrators voted by 3:2 to dismiss a claim that probably required an award concerning territorial sovereignty over the archipelago and did not judge the issue regarding the legality of relevant sovereign acts. The rise of jurisdiction over hybrid disputes reflects that judges would have different stances towards their own power. ${ }^{32}$ However, such rise is extremely likely to cause difficulties in realizing effectively the initial legislative intention and purpose of the obligation to exchange views under the UNCLOS framework in maritime dispute settlement practice. Thus, the aim of peaceful settlement of dispute that the UNCLOS eagerly advocates is undermined.

\section{Explication on the Obligation to Exchange Views from the Perspective of Treaty Interpretation: A Review on the South China Sea Arbitration}

\section{A. Systematic Interpretation of the Obligation to Exchange Views}

The arbitral tribunal regarded 15 claims that the Philippines filed as a package deal and awarded it preliminary jurisdiction. During the process, the tribunal should have fully invoked Article 283 of the UNCLOS, played its legislative role, and taken an extremely prudent attitude towards jurisdiction that Article 283 requires "The Purpose and Aim" of Article 283 applies especially to interpreting the basic document of establishing an international organization because such a rule may compel its updating with the developments of the era, thereby compensating for deficiencies in the treaty and bridging the gap between the treaty and reality. ${ }^{33}$ The dispute settlement mechanism of the UNCLOS especially emphasizes the settlement

31 Chagos Marine Protected Area Arbitration (Mauritius v. U.K.), Perm. Ct. Arb. Award 89-90, ๆף 215-219 (Mar. 18, 2015), available at https://files.pca-cpa.org/pcadocs/MU-UK\%2020150318\%20Award.pdf.

32 QiangYe, On Challenges of International Justice Intervention in Rights and Interests Disputes over the Sea Surrounding China from “Two Cases” [从 “两案” 看我国周边海洋权益斗争面临的国际司法干预挑战], WorLd AFF. [世界知识] 26 (2015).

33 Jie Song, Study on the Interpretation of Judicial Practice in International Court of Justice [国际法院司法实践 中的解释问题研究]18 (Wuhan University Press, 2008). 
of maritime disputes through negotiation and other peaceful means, which runs through the whole system and framework of the UNCLOS. If negotiation and other peaceful means are weakened or surrendered in settling disputes concerning the interpretation or application of the UNCLOS, the complex nature of the maritime disputes shall require reviewing such dispute through highly rigorous procedures.

The complex nature of the maritime dispute also lies in the enforceability of the award concerning said dispute; such award otherwise would be meaningless. Whether a dispute settlement mechanism is effective should not be assessed just by answering whether the adjudicating agency can expand the scope of jurisdiction of compulsory procedures, but it should focus on the degree to which disputants' comply with the award. ${ }^{34}$ Therefore, from a systematic interpretation perspective, the 'degree' and 'standard' of performance of the obligation to exchange views shall be determined with regard to the enforceability of the award concerning the maritime dispute; otherwise, such dispute would be finally resolved. Unfortunately, the arbitral tribunal of the South China Sea case seems to have totally forgotten this point.

The dispute between China and the Philippines over the South China Sea has existed for numerous years. Such means are available for them like negotiation or consultation. Important legal instruments such as the Declaration on the Conduct of Parties in the South China Sea was adopted as well. Both countries shall appreciate these pivotal means or mechanisms for their maritime disputes and fully 'exhaust' these tools to settle maritime disputes by peaceful means. Therefore, the obligation to exchange views under Article 283 of the UNCLOS should have played its role on basis of exhausting relevant agreements. However, the tribunal of South China Sea Arbitration did not pay sufficient attention to the critical value of the obligation to exchange views, but just regarded the performance of such obligation as a 'formality.' The UNCLOS designates arbitration under Annex VII as the only remaining method for settling a dispute concerning the interpretation or application of the UNCLOS, excluding the free will of State Parties. This position results in highly frequent arbitration of Annex VII. ${ }^{35}$ The defects in the dispute settlement mechanism of the UNCLOS add complexity and cause difficulties in enforcing dispute resolutions.

34 Zan He, On Interpretation of Declaration on Optional Exceptions to Compulsory Procedures in the Convention on the Law of the Sea-Taking the Dispute between China and the Philippines over the South China Sea [海洋法公约强制程序 任择性例外声明的解释问题-以中菲南海争端为例], 4 WUHAN U. J. (Philosophy \& Social Sciences) [武汉大学学报 (哲 学社会科学版)] 57-61 (2014).

35 Heng Liu, On Arbitration Set Forth in Annex VII to United Nations Convention on the Law of the Sea: Orientation, Manifestation and Problems-Also on the Lesson Drawn on from South China Sea Arbitration [联合国海洋法公约附件 七仲裁: 定位、表现与问题-兼谈对“南海仲裁案”的启示], 5 INT’L L. REv. [国际法研究] 21 (2015). 


\section{B. Evolving Interpretation of the Obligation to Exchange Views}

Philippine lawyers insisted on automatically applying Annex VII to the UNCLOS when they reviewed the South China Sea Arbitration between China and the Philippines. ${ }^{36}$ In specific maritime disputes, the adjudicating agency loosely and flexibly interprets the obligation to exchange views under Article 283 of the UNCLOS. The arbitral tribunal considered that the views exchanged can be procedural or substantive, and the exchange of procedural views on the choice of means for dispute settlement inevitably includes consultation on substantive issues. ${ }^{37}$ The maritime disputes between China and the Philippines did not develop in a day, but involves historical, political, economic and diplomatic factors.

As time passes by, the legislative foundation for the obligation to exchange views set forth in Article 283 of the UNCLOS, the environment of the international community, the types and theories of maritime disputes have much evolved. However, the interpretation and application of Part XV of the UNCLOS to maritime disputes have not advanced yet. When confronted with a maritime dispute, the UNCLOS needs to refer continuously to general international law standards.

The maritime dispute should be interpreted according to the legislative purposes and aims of the UNCLOS and then solved. ${ }^{38}$ In the Chagos Marine Protected Area Arbitration between Mauritius and the UK, the UK considered that Article 283 should be interpreted strictly, and both parties should reach a consensus on issues such as what the 'dispute' is. ${ }^{39}$ In the South China Sea Arbitration, the PCA should have understood the complexity and dynamics of the dispute and thus more prudently delivered an award on the preliminary jurisdiction. However, it is regrettable that the tribunal did not deal with this issue adequately.

In many maritime disputes, a disputant would initiate the compulsory procedure of arbitration based on existing relevant agreements or conventions. In light of relevant agreement and dialogue mechanisms in place between China and the

36 L. Bautista, The Philippine Claim to Bajo de Masinloc in the Context of the South China Disputes, 6 J. EAST AsIA \& INT'L L. 523 (2013).

37 A. Vermeer-Kiinzli, The Merits of Reasonable Flexibility: The Contribute of the law of Treaties to Peace, in PEACE through International Law: The Role of the International Law Commission. A Colloquium at the Occasion of its Sixtieth AnNIVERSARy 78 (G. Nolteed ed., 2009).

38 A. Boyle, Further Development of the Law of the Sea Convention: Mechanisms for Change, 3 INT'L \& Comp. L. Q. 563-84 (2005).

39 Xiaoyi Zhang \& Maoliqiusi Su, Review on the Chagos Arbitration between Mauritius and United Kingdom-Also on the Latest Development of South China Sea Arbitration between China and the Philippines [毛里求斯诉英国查戈斯仲裁案 述评-结合菲律宾诉中国南海仲裁案的最新进展], 12 PACIFIC J. [太平洋学报] 23-31 (2015). See also Arbitration under Annex VII of the 1982 United Nations Convention on the law of the sea (Mauritius v. U.K): Memorial of the Republic of Mauritius, vol. I, at 2, $\uparrow 1.5$, available at https://pcacases.com/web/sendAttach/1796. 
Philippines on South China Sea disputes, the arbitral tribunal should cautiously pay attention to existing mechanisms and manners of settling maritime disputes between China and the Philippines by peaceful means while proceeding with the compulsory arbitration procedure.

The Philippines and the arbitral tribunal constituted according to Annex VII to the UNCLOS should have considered sufficient reasons to understand the complexity of maritime disputes between China and the Philippines and be enough prudent in explaining the obligation to exchange views set forth in Article 283 of the UNCLOS. The essence of evolving interpretation requires this. The initial legislative intention of the obligation to exchange views under Article 283 of the UNCLOS may require progressive interpretation because of the evolving practices of maritime disputes. That is to say, such interpretation should be applied in understanding the legal theory contained in Article 283 of the UNCLOS, which cannot be arbitrarily regarded as belonging to a typical procedural rule simply on the basis of the structural position of its text. The arbitral tribunal may, based on evolving interpretation of a treaty, clarify detailed obligations on what the obligation to exchange views is and how it effectively prevents a case from easily entering into the compulsory jurisdiction procedure.

\section{Preliminary System Design for Improving the Obligation to Exchange Views under the UNCLOS}

\section{A. How to Enhance the Disputants' Obligation of Disclosure?}

Stefan Talmon reviewed the South China Sea Arbitration and considered that the arbitral tribunal could accept the application filed by the Philippines only after both parties had performed the obligation to exchange views. ${ }^{40}$ The exchange of views under the UNCLOS is a bilateral behavior. Therefore, the notice from the Philippines inviting China to submit the dispute to an arbitration could not fall into the scope of the exchange of views. ${ }^{41}$ However, the complexity of maritime disputes or disputes concerning the interpretation or application of the UNCLOS cause a disputant's

40 S. Talmon, The South China Sea Arbitration: Is There a Case to Answer?, in The South China Sea Arbitration: A Chinese Perspective 15-9 (S. Talmon \& Bing Bing Jia eds., 2014).

41 Wenjie Li \& Ligang Zou, Jurisdiction of International Tribunal for the Law of the Sea over the Claim Filed by the Philippines against China [国际海洋法仲裁法庭对菲律宾诉中国案的管辖权问题研究], 5 CONTEMP. L. REv. [当代法学] 152 (2014). 
claims to be packaged elaborately on the basis of its own interests, which results in substantial confusion for the adjudicating agency to ascertain the preliminary jurisdiction and admissibility of application.

Anglo-American procedural law, which pervades international dispute settlement mechanisms, provides the basis for enhancing the disputants' obligation of disclosure. Therefore, such obligation becomes an essential link in interpreting correctly the obligation to exchange views. ${ }^{42}$ In short, the disputants' obligation of disclosure requires that the claims filed by a disputant specify the scope of the 'dispute' and packaged claims be precluded. Meanwhile, the disputants should disclose in good faith whether and how they exchange views; otherwise, the disputants would be acting fraudulently against the adjudicating agency and must accept the adverse consequences in the award because of their deliberately concealment of relevant critical issues. $^{43}$

The categorization of maritime disputes is a pivotal issue regarding the obligation of disclosure in course of exchanging views. How to categorize maritime disputes is a rather puzzling and difficult question. The Tübingen Approach holds that the nature of an issue determines a way of solution and system building does a manner of settling a conflict. ${ }^{44}$ Considering the core characteristic of international maritime disputes, it is necessary to categorize the current disputes and then discover respective settlement mechanisms and manners suitable for each category of maritime disputes according to their respective characteristics. The UNCLOS provides us with a basic framework for it. ${ }^{45}$ Therefore, based on the categorization of maritime disputes under the framework of the UNCLOS, to summarize new, continuously developed categories of maritime disputes may not only increasingly improve the disputants' obligation of disclosure, but also provide approaches and judicial experience for further improving the obligation to exchange views under the UNCLOS.

42 R. Millar, Civil Procedure of the Trial Court in Historical Perspective 12 (1952).

43 The Bunge Melati 5 [2012] SGCA (Singapore Court of Appeal) 46, Civil Appeal No. 193 of 2010 (Aug. 21, 2012), available at https://www.singaporelawwatch.sg/Portals/0/Docs/Judgments/[2012]\%20SGCA\%2046.pdf.

45 The UNCLOS sets forth the principles such as "international navigation," "utilization of marine resources," "conservation and preservation of marine environment," "delimitation of the sea," "sovereignty," "sovereign rights," "jurisdiction," and "scientific research," etc. Those provide foundation to understand the types of maritime disputes under the UNCLOS framework. 


\section{B. The Adjudicating Agency's Obligation of Due Diligence}

Echoing the obligation of disclosure imposed on the disputants, the adjudicating agency, faced with a complicated maritime dispute claim, should undertake the obligation of due diligence, which is a critical link to improving the obligation to exchange views. The adjudicating agency's due diligence obligation, echoing the disputants' disclosure obligation, requires to substantively review the extent and effect of performing the obligation to exchange views based on the claims that the applicant or claimant submitted and, thus, issue an award deciding whether the preliminary jurisdiction and admissibility of the case exists. In international maritime disputes, numerous practical experiences show whether the preliminary jurisdiction exists.

The Northern Cameroons Case demonstrates that the court must notice its own inner limits in exercising judicial functions. The role of a court is to maintain its judicial essence rather than satisfy one or both parties' 'unrealistic' requests. The court itself must protect judicial principles. ${ }^{46}$ Straits of Johor Land Reclamation further developed the idea of examinational review. The International Tribunal for the Law of the Sea emphasized that its assessment of a case does not totally depend on the subjective judgment of the disputants, which demonstrates the tendency that the adjudicating agency is willing to undertake the obligation of due diligence in review. ${ }^{47}$ The enhancement of due diligence in review by the adjudicating agency will inevitably guarantee the dispute settlement mechanism for the substantive review and assessment of the obligation to exchange views set forth in Article 283 of the UNCLOS.

\section{Conclusion}

The South China Sea Arbitration initiated by the Philippines further demonstrates the predicament that the dispute settlement mechanism of the UNCLOS fails to effectively deal with maritime disputes. The absence of the obligation to exchange views set forth in Article 283 of the UNCLOS reflected in the maritime disputes settlement mechanism once resulted in the adjudicating agency's abuse of the dispute

46 Case concerning Northern Cameroons (Cameroon v. U.K.), Preliminary Objections, 1963 ICJ Rep. 18, ๆ 29 (Dec. 2), available at https://www.icj-cij.org/files/case-related/48/048-19631202-JUD-01-00-EN.pdf.

47 D. Devine, Compulsory Dispute Settlement in the UNClos Undermined? 98 (2000). 
mechanism. The arbitral tribunal of the South China Sea Arbitration arbitrarily interpreted substantive contents of the UNCLOS and expounded maritime disputes between China and the Philippines based on outdated or old historical theories on the law of the sea or an arbitrator's personal orientation that deviates from the real purposes of the UNCLOS. International law is common knowledge improving through compiling and gradual development. ${ }^{48}$

The arbitral tribunal should have been prudent in filing the South China Sea Arbitration and provided a classic, influential, and good-law-complying case for the development of international law. Unfortunately, the arbitral tribunal appears to have almost totally forgotten the complexity of the South China Sea dispute itself and the simmering crisis behind the case. The award of the arbitral tribunal was destructive rather than constructive in finding the rule of law in the international society. However, evil also provides opportunity for good. In a different sense, the final award of the South China Sea Arbitration is probably optimal for improving and constructing a just order on the seas because human beings are making progress in the international rule of law by continuous reflection and drawing lessons from mistakes. 